\title{
Technical Progress Report on Single Pass Flow Through Tests of Ceramic Waste Forms for Plutonium Immobilization
}

\author{
P. Zhao, S. Roberts, W. Bourcier
}

December 3, 2000 


\section{DISCLAIMER}

This document was prepared as an account of work sponsored by an agency of the United States Government. Neither the United States Government nor the University of California nor any of their employees, makes any warranty, express or implied, or assumes any legal liability or responsibility for the accuracy, completeness, or usefulness of any information, apparatus, product, or process disclosed, or represents that its use would not infringe privately owned rights. Reference herein to any specific commercial product, process, or service by trade name, trademark, manufacturer, or otherwise, does not necessarily constitute or imply its endorsement, recommendation, or favoring by the United States Government or the University of California. The views and opinions of authors expressed herein do not necessarily state or reflect those of the United States Government or the University of California, and shall not be used for advertising or product endorsement purposes.

This work was performed under the auspices of the U.S. Department of Energy by the University of California, Lawrence Livermore National Laboratory under Contract No. W-7405-Eng-48.

This report has been reproduced directly from the best available copy.

Available electronically at http://www.doe.gov/bridge

Available for a processing fee to U.S. Department of Energy

and its contractors in paper from

U.S. Department of Energy

Office of Scientific and Technical Information

P.O. Box 62

Oak Ridge, TN 37831-0062

Telephone: (865) 576-8401

Facsimile: (865) 576-5728

E-mail: reports@adonis.osti.gov

Available for the sale to the public from

U.S. Department of Commerce

National Technical Information Service

5285 Port Royal Road

Springfield, VA 22161

Telephone: (800) 553-6847

Facsimile: (703) 605-6900

E-mail: orders@ntis.fedworld.gov

Online ordering: http://www.ntis.gov/ordering.htm

OR

Lawrence Livermore National Laboratory

Technical Information Department's Digital Library

http://www.llnl.gov/tid/Library.html 
Technical Progress Report on Single Pass Flow Through Tests Of Ceramic Waste Forms for Plutonium Immobilization

Pihong Zhao

Sarah Roberts

William Bourcier

Lawrence Livermore National Laboratory

December 3, 2000 


\section{INTRODUCTION}

This report updates work on measurements of the dissolution rates of single-phase and multi-phase ceramic waste forms in flow-through reactors at Lawrence Livermore National Laboratory. Previous results were reported in Bourcier (1999)*.

Two types of tests are in progress: (1) tests of baseline pyrochlore-based multiphase ceramics; and (2) tests of single-phase pyrochlore, zirconolite, and brannerite (the three phases that will contain most of the actinides). Tests of the multi-phase material are all being run at $25^{\circ} \mathrm{C}$. The single-phase tests are being run at $25^{\circ}, 50^{\circ}$, and $75^{\circ} \mathrm{C}$. All tests are being performed at ambient pressure. The as-made bulk compositions of the ceramics are given in Table 1.

The single pass flow-through test procedure [Knauss, $1986 \# 140$ ] allows the powdered ceramic to react with $\mathrm{pH}$ buffer solutions traveling upward vertically through the powder. Gentle rocking during the course of the experiment keeps the powder suspended and avoids clumping, and allows the system to behave as a continuously stirred reactor. For each test, a cell is loaded with approximately one gram of the appropriate size fraction of powdered ceramic and reacted with a buffer solution of the desired $\mathrm{pH}$. The buffer solution compositions are given in Table 2.

All the ceramics tested were cold pressed and sintered at $1350^{\circ} \mathrm{C}$ in air, except brannerite, which was sintered at $1350^{\circ} \mathrm{C}$ in a $\mathrm{CO} / \mathrm{CO}_{2}$ gas mixture. They were then crushed, sieved, rinsed repeatedly in alcohol and distilled water, and the desired particle size fraction collected for the single pass flow-through tests (SPFT). The surface area of the ceramics measured by BET ranged from $0.1-0.35 \mathrm{~m}^{2} / \mathrm{g}$. The measured surface area values, average particle size, and sample weights for each ceramic test are given in the Appendices.

\footnotetext{
* Bourcier, W. L. (1999). Interim report on development of a model to predict dissolution behavior of the titanate waste form in a repository and compilation of data from SPFT ceramic dissolution tests (FY99 milestones 4.1e and 4.1f), Lawrence Livermore National Laboratory, UCRL-ID-135363, PIP-00-003. 55 p.
} 
Table 1. Compositions of ceramics used in SPFT dissolution tests.

\begin{tabular}{|c|c|c|c|c|c|c|c|c|c|}
\hline \multirow{3}{*}{ Oxide } & \multirow{3}{*}{ Element } & \multicolumn{4}{|c|}{ P104 } & \multicolumn{4}{|c|}{ Impure Feed (Batch 4) } \\
\hline & & \multicolumn{2}{|c|}{ Oxide } & \multicolumn{2}{|c|}{ Element } & \multicolumn{2}{|c|}{ Oxide } & \multicolumn{2}{|c|}{ Element } \\
\hline & & $w t \%$ & mole\% & $w t \%$ & mole $\%$ & $w t \%$ & mole\% & $\mathrm{wt} \%$ & mole\% \\
\hline & $\mathrm{O}$ & -- & -- & 25.1 & 63.6 & -- & -- & 24.1 & 63.8 \\
\hline $\mathrm{CaO}$ & $\mathrm{Ca}$ & 12.6 & 25.0 & 9.0 & 9.1 & 9.9 & 21.2 & 7.1 & 7.5 \\
\hline $\mathrm{UO} 2$ & $\mathrm{U}$ & 30.2 & 12.5 & 26.7 & 4.5 & 23.6 & 10.5 & 20.8 & 3.7 \\
\hline $\mathrm{PuO} 2$ & $\mathrm{Pu}$ & -- & -- & -- & -- & 11.9 & 5.2 & 10.5 & 1.8 \\
\hline $\mathrm{CeO} 2$ & $\mathrm{Ce}$ & 9.6 & 6.3 & 7.8 & 2.3 & -- & -- & -- & -- \\
\hline $\mathrm{Gd} 2 \mathrm{O} 3$ & $\mathrm{Gd}$ & -- & -- & -- & -- & 7.9 & 2.6 & 6.9 & 1.8 \\
\hline $\mathrm{TiO} 2$ & $\mathrm{Ti}$ & 35.8 & 50.0 & 21.4 & 18.2 & 35.9 & 54.1 & 21.5 & 19.0 \\
\hline $\mathrm{HfO} 2$ & $\mathrm{Hf}$ & 11.8 & 6.3 & 10.0 & 2.3 & 10.6 & 6.1 & 9.0 & 2.1 \\
\hline $\mathrm{Ga} 2 \mathrm{O} 3$ & $\mathrm{Ga}$ & -- & -- & -- & -- & 0.14 & 0.09 & 0.10 & 0.06 \\
\hline $\mathrm{ZnO}$ & $\mathrm{Zn}$ & -- & -- & -- & -- & 0.11 & 0.14 & 0.07 & 0.05 \\
\hline \multirow{2}{*}{$\mathrm{MgO}$} & $\mathrm{Mg}$ & -- & -- & -- & -- & 0.02 & 0.06 & 0.01 & 0.02 \\
\hline & & \multicolumn{4}{|c|}{ P139 (zirconolite ceramic) } & \multicolumn{4}{|c|}{ P137 (pyrochlore ceramic) } \\
\hline \multirow[t]{3}{*}{ Oxide } & Element & \multicolumn{2}{|c|}{ Oxide } & \multicolumn{2}{|c|}{ Element } & \multicolumn{2}{|c|}{ Oxide } & \multicolumn{2}{|c|}{ Element } \\
\hline & & $\mathrm{wt} \%$ & mole\% & $w t \%$ & mole\% & $\mathrm{wt} \%$ & mole $\%$ & wt $\%$ & mole\% \\
\hline & $\mathrm{O}$ & & & 24.9 & 64.0 & -- & -- & 24.9 & 63.8 \\
\hline $\mathrm{CaO}$ & $\mathrm{Ca}$ & 9.7 & 20.2 & 6.9 & 7.1 & 10.5 & 21.7 & 7.5 & 7.7 \\
\hline $\mathrm{UO} 2$ & $\mathrm{U}$ & 16.1 & 7.0 & 14.2 & 2.5 & 24.3 & 10.4 & 21.4 & 3.7 \\
\hline $\mathrm{PuO} 2$ & $\mathrm{Pu}$ & -- & -- & -- & -- & -- & -- & -- & -- \\
\hline $\mathrm{CeO} 2$ & $\mathrm{Ce}$ & 6.4 & 4.3 & 5.2 & 1.5 & 8.4 & 5.7 & 6.9 & 2.0 \\
\hline $\mathrm{Gd} 2 \mathrm{O} 3$ & $\mathrm{Gd}$ & 6.9 & 2.2 & 6.0 & 1.6 & 8.1 & 2.6 & 7.1 & 1.8 \\
\hline $\mathrm{TiO} 2$ & $\mathrm{Ti}$ & 35.5 & 52.1 & 21.3 & 18.3 & 36.2 & 52.7 & 21.7 & 18.6 \\
\hline $\mathrm{HfO} 2$ & Hf & 25.4 & 14.1 & 21.5 & 5.0 & 12.5 & 6.9 & 10.6 & 2.4 \\
\hline $\mathrm{Ga} 2 \mathrm{O} 3$ & $\mathrm{Ga}$ & -- & -- & -- & -- & -- & -- & -- & -- \\
\hline $\mathrm{ZnO}$ & $\mathrm{Zn}$ & -- & -- & -- & -- & -- & -- & -- & -- \\
\hline \multirow[t]{2}{*}{$\mathrm{MgO}$} & $\mathrm{Mg}$ & -- & - & - & - & - & - & -- & -- \\
\hline & & \multicolumn{4}{|c|}{ Brannerite } & & & & \\
\hline \multirow[t]{2}{*}{ Oxide } & Element & \multicolumn{2}{|c|}{$\begin{array}{c}\text { Oxide } \\
w t \% \text { mole } \%\end{array}$} & \multicolumn{2}{|c|}{ Element } & & & & \\
\hline & $\mathrm{O}$ & -- & -- & 22.8 & 66.7 & & & & \\
\hline UO2 & $\mathrm{U}$ & 61.1 & 31.7 & 53.9 & 10.6 & & & & \\
\hline $\mathrm{TiO} 2$ & $\mathrm{Ti}$ & 38.9 & 68.3 & 23.3 & 22.8 & & & & \\
\hline
\end{tabular}

The flow-through tests were run at various flow rates ranging from 10 to $100 \mathrm{ml} /$ day. The flow rates for each test are given in the Appendices. Peristaltic pumps were used to control flow rate. A debubbler cell was placed in line for each buffer solution. The debubbler allows the gas exsolved during heating of the fluid to escape, avoiding the capture of bubbles inside the reaction chamber. 
Table 2. Buffer solution compositions.

\begin{tabular}{|c|c|c|}
\hline $\mathrm{pH}$ & Buffer Components & Concentration \\
\hline $\mathrm{pH} 2$ & $\mathrm{HCl}$ & 0.01 molal \\
\hline $\mathrm{pH} 4$ & Potassium acid phthalate- $\mathrm{HCl}$ & $0.001 \mathrm{molal}$ \\
\hline $\mathrm{pH} 6$ & Potassium acid phthalate- $\mathrm{NaOH}$ & $0.001 \mathrm{molal}$ \\
\hline $\begin{array}{l}\mathrm{pH} 8 \\
\mathrm{pH} 8.5\end{array}$ & $\begin{array}{l}\text { Boric acid-NaOH } \\
\mathrm{NaHCO}_{3}\end{array}$ & $\begin{array}{l}0.005 \text { molal } \\
0.005 \text { molal }\end{array}$ \\
\hline $\mathrm{pH} 10$ & Boric acid-NaOH & 0.005 molal \\
\hline $\mathrm{pH} 12$ & $\mathrm{NaOH}$ & 0.01 molal \\
\hline $\mathrm{pH} 12$ & $\mathrm{Na}_{2} \mathrm{CO}_{3}-\mathrm{NaOH}$ & 0.01 molal \\
\hline$\overline{\mathrm{pH} 12}$ & $\mathrm{~K}_{2} \mathrm{HPO}_{4}-\mathrm{NaOH}$ & 0.01 molal \\
\hline
\end{tabular}

The reacted solutions were periodically sampled, weighed to determine flow rates, and analyzed by ICP/MS for cerium, gadolinium, hafnium, titanium, and uranium. The concentration data were used to compute the normalized release rate, which is defined as:

$$
N R_{i}=\frac{C_{i} * Q}{S * m * X_{i}}
$$

where $C_{i}$ is the blank-corrected concentration of element $i$ in the buffered leach solution (per unit volume), $Q$ is the solution flow rate, $S$ is the BET-measured specific surface area of the ceramic, $m$ is the mass of ceramic, and $X_{i}$ is the weight fraction of element $i$ in the ceramic. Normalized release rates in units of $\mathrm{g} / \mathrm{m}^{2} /$ day for each element are given in the Appendices. 


\section{SUMMARY OF DATA}

Tests of the U-Pu multi-phase pyrochlore-based ceramic waste form

The SPFT tests of the plutonium-bearing pyrochlore-based ceramic were carried out in $\mathrm{pH}$ buffers of 2, 4 and 6 at room temperature. The tests have been ongoing for 34 months. Figure 1 shows the dissolution rates of $\mathrm{Pu}$ and $\mathrm{U}$ as a function of time at the three $\mathrm{pH}$ values tested. Release rates are highest at low $\mathrm{pH}$. At a given time and $\mathrm{pH}$, the normalized release rates for $\mathrm{U}$ and $\mathrm{Pu}$ are approximately the same. The release rates decrease with time, and the effect of $\mathrm{pH}$ tends to decrease with time.

Figure 2 compares the dissolution rates of all the elements (except $\mathrm{Ca}$ ) in the U-Pu ceramic at each $\mathrm{pH}$ tested. The elemental release becomes more non-stoichiometric as the solution $\mathrm{pH}$ increases from 2 to 6 . However, even at $\mathrm{pH}$ 6, elemental releases become more congruent with time. The concentrations of some elements such as $\mathrm{Hf}$ and $\mathrm{Ti}$ in $\mathrm{pH}$ 6 leachate are near or below the detection limits of ICP-MS. The amounts of Ca released from the ceramic were below background because of the high background levels of $\mathrm{Ca}$ under standard laboratory conditions.

Tests of the U-Ce multi-phase pyrochlore-based ceramic waste form

Two sets of room temperature SPFT tests of the U-Ce ceramic are in progress; tests at $\mathrm{pH} 2,4,6$, and 8; and tests at $\mathrm{pH} \mathrm{9,10}$ and 12. Ce serves as an analog for $\mathrm{Pu}$ in these ceramics. Because the ceramic contains no $\mathrm{Pu}$ the tests do not need to be performed in a glovebox. The $\mathrm{pH}$ 2-8 tests have been ongoing for 35 months. The $\mathrm{pH} 9-12$ tests have been ongoing for 28 months. Figure 3 shows the normalized release rates for elements in the $\mathrm{U}-\mathrm{Ce}$ pyrochlore ceramic waste form as a function of time. The data trends are consistent with those obtained from the tests of U-Pu ceramic samples. The normalized release rates of uranium at $\mathrm{pH} 2$ to 9 clearly continued to decrease for the duration of the 
tests; however, the release rates at higher $\mathrm{pHs}$ seem to have leveled off between 1.5 and 2 years. Note that although $\mathrm{Ce}$ and $\mathrm{U}$ are released congruently at low $\mathrm{pH}$ values (Figure 3), at $\mathrm{pH} 8$ and higher, $\mathrm{U}$ is released faster than $\mathrm{Ce}$. This probably is due to a lower relative solubility of $\mathrm{Ce}$ vs. $\mathrm{U}$ at neutral to alkaline $\mathrm{pH}$ values.

At pH 12, three different buffers were used to study the effects of various anions (hydroxide, carbonate, and phosphate) on dissolution behavior. After a year of reaction, uranium release rates started showing a dependence on solution composition (see Figure 4a). The release rate of uranium in these buffers decreases in the order: $\mathrm{Na}_{2} \mathrm{CO}_{3}>\mathrm{NaOH}$ $>\mathrm{K}_{2} \mathrm{HPO}_{4}$. The anion species apparently participate in the reactions controlling the release of U. However, Ti and Hf do not appear to be affected by the anion present, at the resolution of our tests (Figures $4 \mathrm{~b}$ and $4 \mathrm{c}$ ).

Two more SPFT tests (at pH 2 \& 4) for the multiphase ceramic BSL8 (received from PNNL) at room temperature were started in February 2000. An earlier sample of this formulation tested at PNNL showed anomalous release rate data; normalized release rates for some elements increased with time. No analytical data are currently available from our tests on this material. Data on this test will be reported in the next data update.

\section{Tests of U-Ce single-phase ceramics}

SPFT tests on nominally single-phase pyrochlore ${ }^{1}\left((\mathrm{Ca}, \mathrm{Gd})(\mathrm{Hf}, \mathrm{Ce}, \mathrm{U}, \mathrm{Gd}) \mathrm{Ti}_{2} \mathrm{O}_{6}\right)$, zirconolite $\left((\mathrm{Ca}, \mathrm{Gd})(\mathrm{Hf}, \mathrm{Ce}, \mathrm{U}, \mathrm{Gd}) \mathrm{Ti}_{2} \mathrm{O}_{6}\right)$, and brannerite $\left(\mathrm{UTi}_{2} \mathrm{O}_{6}\right)$ ceramics are being carried out at $25^{\circ}, 50^{\circ}$ and $75^{\circ} \mathrm{C}$ over a $\mathrm{pH}$ range of 2-12. The tests of the pyrochlore and zirconolite have been in progress for 24 months. The tests of the brannerite have been in progress for 15 months. They are all currently being maintained at $75^{\circ} \mathrm{C}$ with infrequent sampling. It should be noted that these ceramics all contain small amounts of rutile and

${ }^{2}$ Although pyrochlore and zirconolite have the same chemical formula, the pyrochlore contains greater amounts of $\mathrm{U}$ and $\mathrm{Ce}$ and a lesser amount of Hf than zirconolite (see Table 1) and because of this crystallizes with a different structure. 
mixed Ti-Hf oxides ( $<10$ volume \%). The pyrochlore ceramic also contains a small amount of brannerite $(<2$ volume \%). The presence of small amounts of other phases may affect the interpretation of the data.

Figures 5 to 7 show normalized uranium release rates observed in each phase at $25^{\circ}, 50^{\circ}$ and $75^{\circ} \mathrm{C}$, respectively. Only uranium data are plotted. Uranium was generally above detection limits at all $\mathrm{pH}$ values and therefore shows the best trends. Other elements were detectable only under a subset of test conditions. The concentrations of all analyzed elements are given in Appendix C, D and E. In general, the highest release rates are obtained for brannerite with rates of $10^{-3}-10^{-4} \mathrm{~g} / \mathrm{m}^{2} /$ day obtained at the longest durations. Rates for pyrochlore and brannerite are typically an order of magnitude lower at similar $\mathrm{pH}$ and temperature.

The data show a progressive increase in non-stoichiometry of release as the $\mathrm{pH}$ increases from 2 to 10 . At $\mathrm{pH} 2, \mathrm{Ca}, \mathrm{U}, \mathrm{Ce}$, and $\mathrm{Ti}$ are all released at nearly the same rate. At higher $\mathrm{pH}$ values, elements other than $\mathrm{U}$ leach at slower rates. Most of the data show a continuous decrease in release rate with time, similar to the $\mathrm{Pu}-\mathrm{U}$ ceramic release rate data.

\section{Summary of dissolution rates as function of $p H$}

Figure 8 compares normalized release rates of uranium for both single phase and multiphase ceramics as a function of $\mathrm{pH}$ at room temperature. The data are averages of measured values over the 90 to 120 day sampling period for all the ceramics except brannerite, for which the 19-26 day data were used. The error bars represent one standard deviation on the average of the analytical data. The curves show a general trend of decreasing dissolution rate with $\mathrm{pH}$ up to near neutral $\mathrm{pH}$, with perhaps a minimum at neutral $\mathrm{pH}$, and little or no effect of $\mathrm{pH}$ at higher $\mathrm{pH}$ values. The single phase zirconolite and pyrochlore ceramics are slightly more durable than the multiphase ceramics. The 
single phase brannerite is about two orders of magnitude less durable than the other single phase ceramics and the multi-phase ceramics. The multi-phase ceramics probably show higher release rates because they contain some of the less durable brannerite phase.

Figure 9 compares beginning and ending normalized release rates for uranium from multiphase ceramics as a function of $\mathrm{pH}$. With time, the release rates slow down, as noted previously. However, the $\mathrm{Ce}-\mathrm{U}$ ceramic release rate slows down more than the $\mathrm{Pu}-\mathrm{U}$ ceramic release rate. This is better seen in Figure 10 where the ratio of the normalized release rate of $U$ from the $\mathrm{Pu}-\mathrm{U}$ ceramic over the normalized release rate of $\mathrm{U}$ from the $\mathrm{Ce}-\mathrm{U}$ ceramic is shown as a function of time. A positive slope of the data indicate the durability of the $\mathrm{Ce}-\mathrm{U}$ ceramic increases with time relative to the $\mathrm{Pu}-\mathrm{U}$ ceramic. The implication is that the data may be showing radiation damage due to alpha decay of $\mathrm{Pu}$ in the $\mathrm{Pu}-\mathrm{U}$ ceramic that is not be present in the $\mathrm{Ce}-\mathrm{U}$ ceramic. A preliminary calculation indicates that something near ten to the twentieth atoms per $\mathrm{cm}^{3}$ would have been displaced from their lattice sites by reason of the alpha decay by during the three year test duration (Rich Van konynenburg, pers. com.). There are a few times ten to the twenty-first atoms per $\mathrm{cm}^{3}$ for this high material, so a couple $\%$ the atoms may have been displaced. Whether this trend is real and whether radiation damage is the cause cannot be determined with a high degree of certainty given the uncertainty of these data.

\section{CONCLUSIONS}

Some generalizations can be made based on these test results. The normalized release rates for most elements continue to decrease with time, although for some materials and $\mathrm{pH}$ conditions, they appear to be at or near steady state (after 3 years). There appear to be no cases where the release rates accelerate dramatically as has been observed in multi-year tests of silicate glasses. At low $\mathrm{pH}$ values, $\mathrm{Hf}$ is released more slowly and $\mathrm{Gd}$ at about the same rate as $\mathrm{Pu}$. At neutral to alkaline $\mathrm{pH}$ values, all of these elements are released at 
rates so slow that analytical limitations make it difficult to determine relative release rates with much certainty.

The single phase tests consistently show that brannerite is the least durable phase, by 1-2 $\log$ units. Zirconolite and pyrochlore appear to be comparable in durability, especially when a correction is made for the small amount of brannerite present in the pyrochlore material.

With time, the effect of $\mathrm{pH}$ on dissolution rate becomes less pronounced, except perhaps for the single phase brannerite.

And finally, in tests at $\mathrm{pH} 12$ with three different anions present (hydroxide, carbonate, and phosphate), carbonate appears to enhance the dissolution rate relative to simple hydroxide, and phosphate decreases the rate relative to simple hydroxide. But the overall effect of the anions is a factor of 10 or less. 

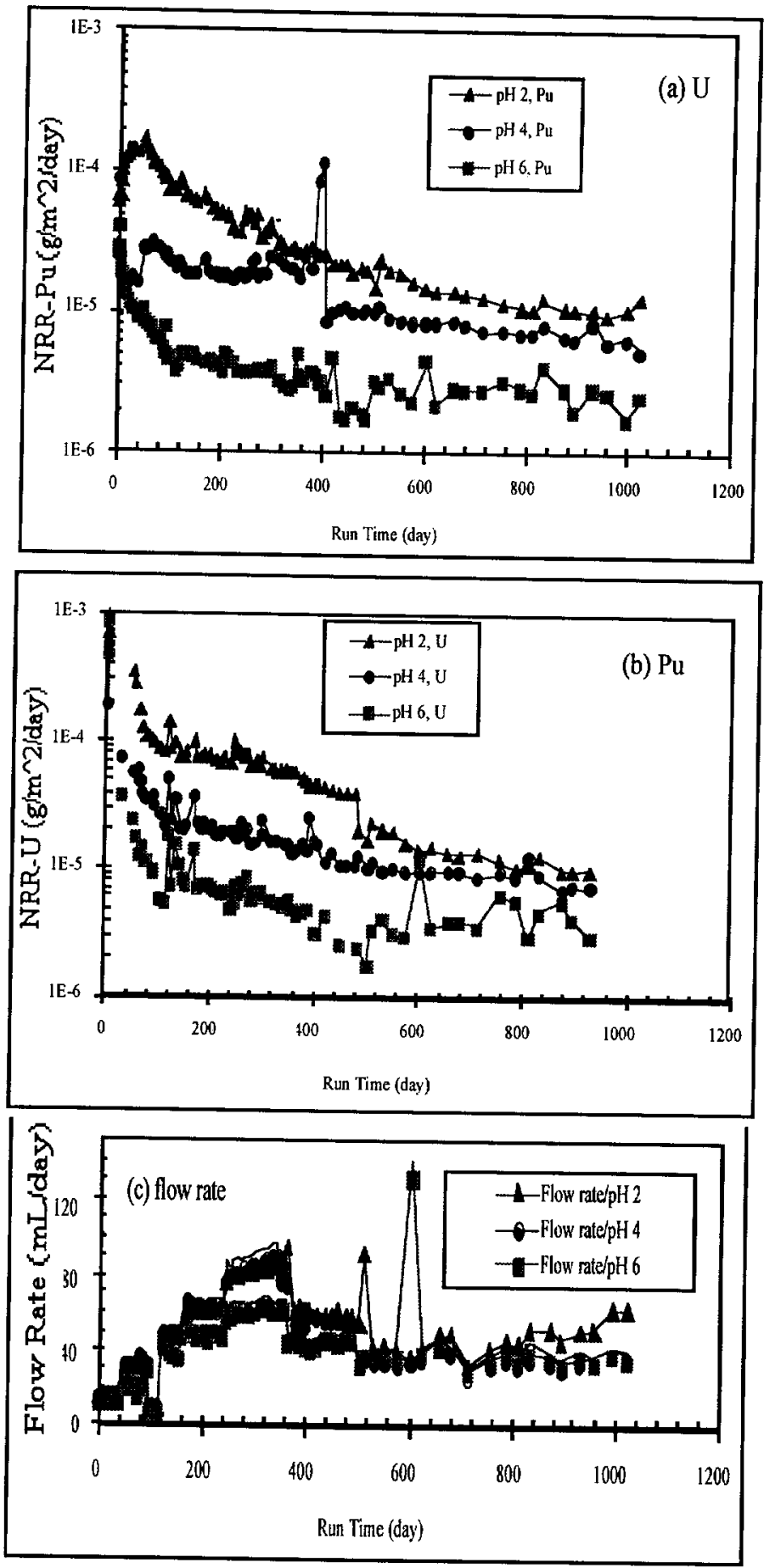

Figure 1. Normalized release rates of elements from the U-Pu multi-phase pyrochlore -based ceramic waste form (Impure Feed, batch 4). (a) normalized release rate of $\mathrm{Pu}$, (b) normalized release rate of $U$, and (c) flow rates. 

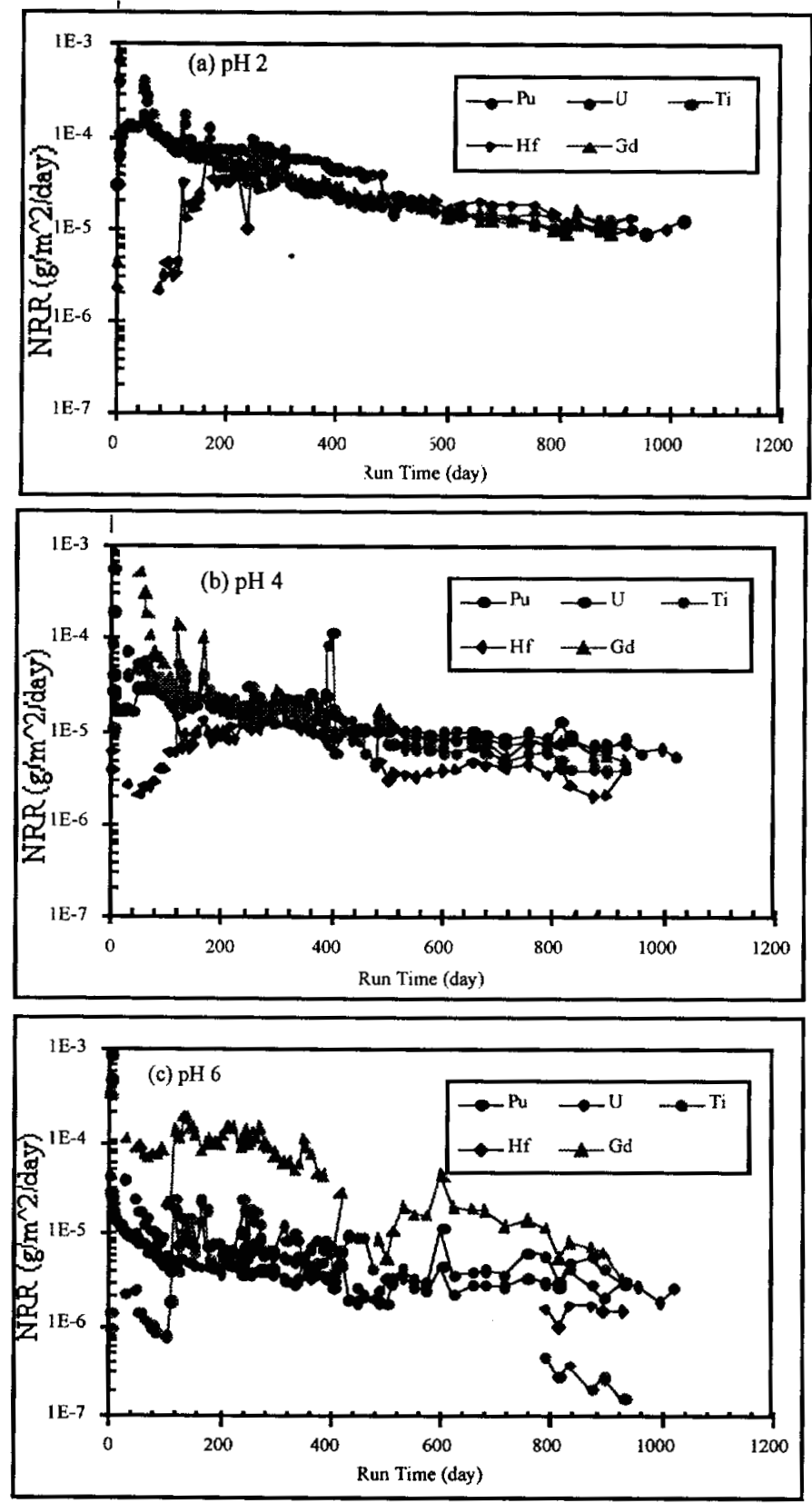

Figure 2. Normalized release rates of plutonium, uranium, titanium, hafnium and gadolinium in U-Pu multi-phase pyrochlore ceramic waste form (Impure Feed, batch 4) at pH (a) 2, (b) 4, and (c) 6 

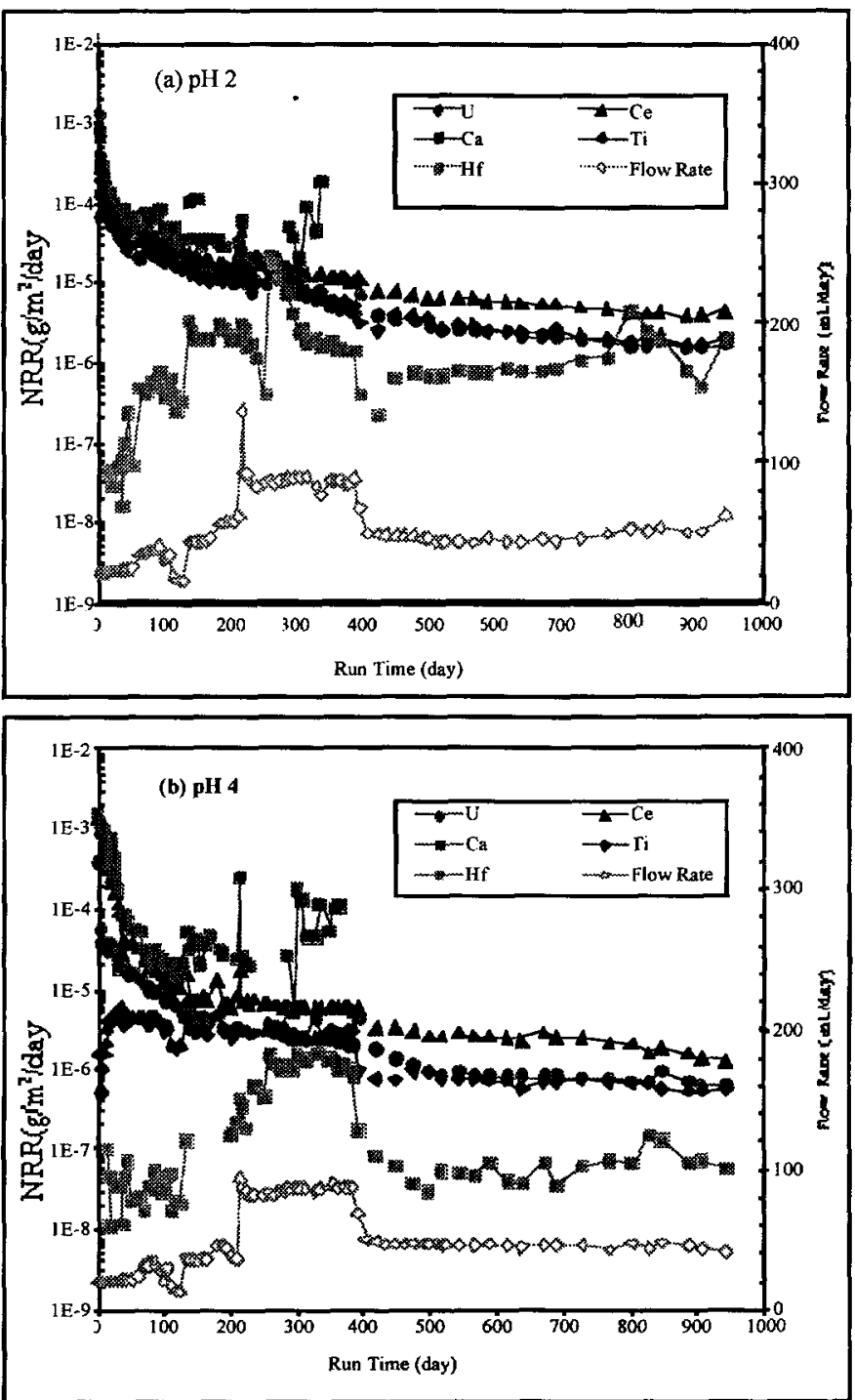

Figure 3. Normalized release rates of major elements in U-Ce multi-phase pyrochlore ceramic waste form (P104) and flow rates at $\mathrm{pH}$ (a) 2, (b) 4 . 

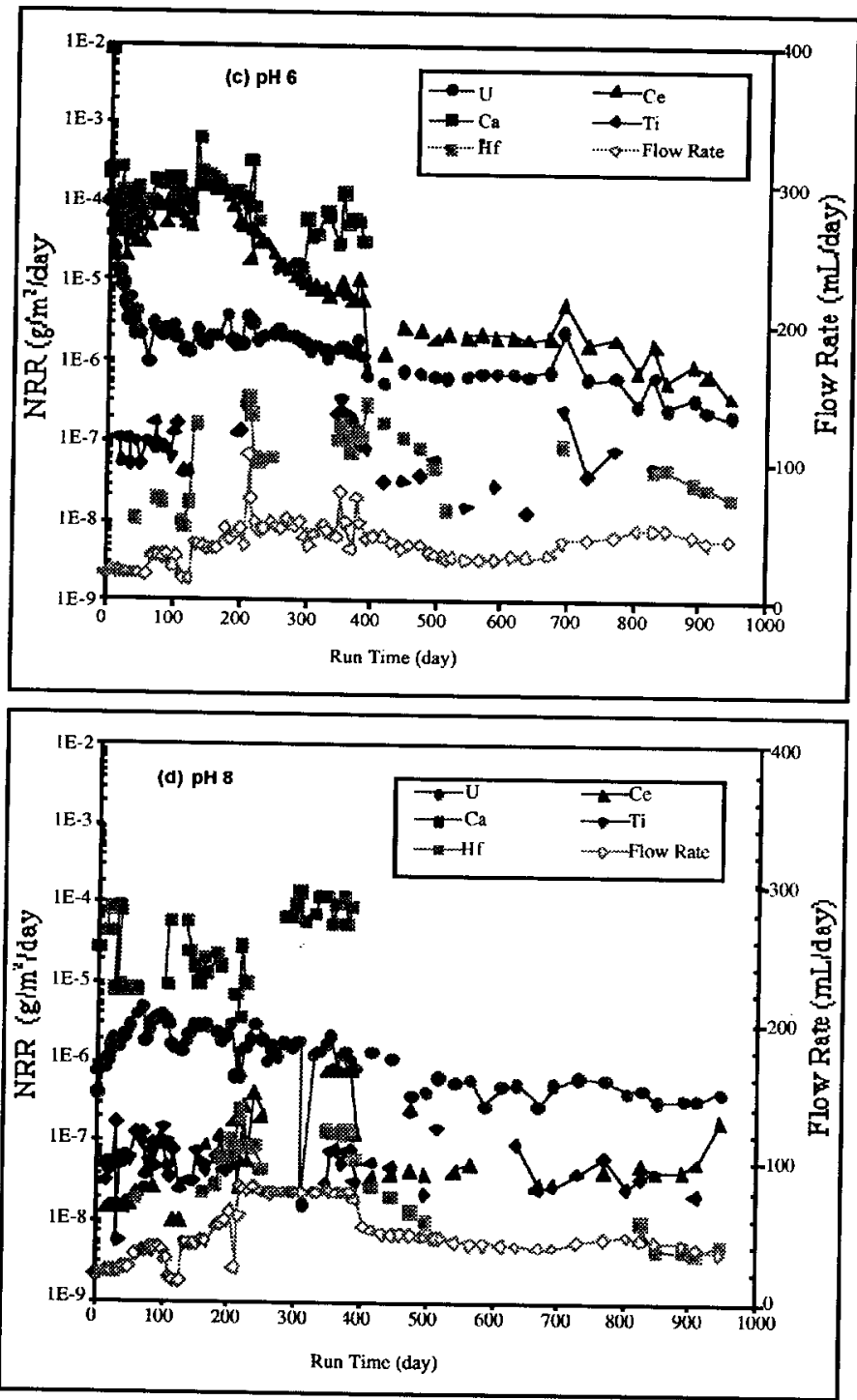

Figure 3 (cont). Normalized release rates of major elements in UCe multi-phase pyrochlore ceramic waste form (P104) and flow rates at $\mathrm{pH}$ (c) 6 , (d) 8 . 

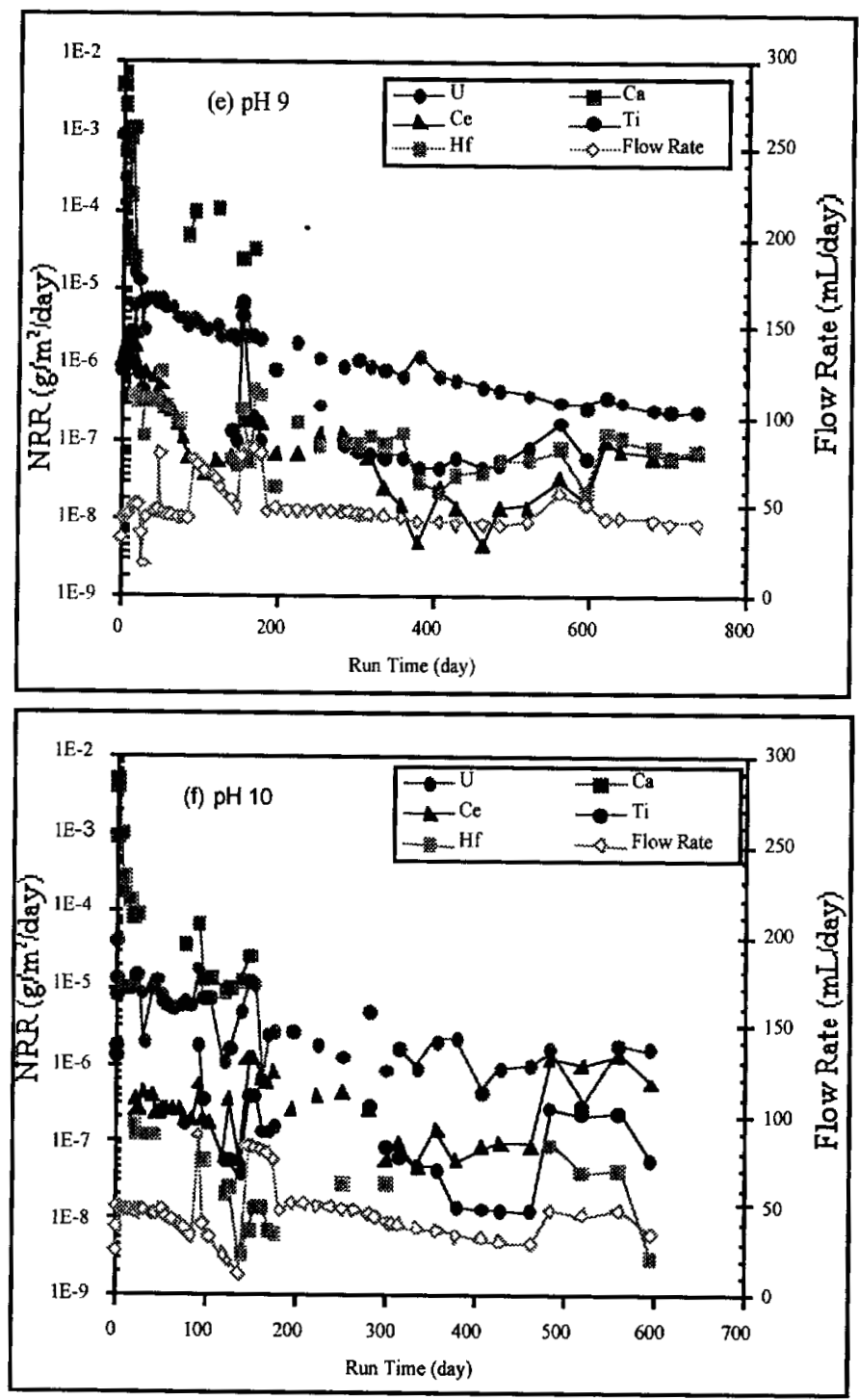

Figure 3 (cont). Normalized release rates of major elements in $\mathrm{U}-\mathrm{Ce}$ multi-phase pyrochlore ceramic waste form (P104) and flow rates at $\mathrm{pH}$ (e) 9, (f) 10 . 

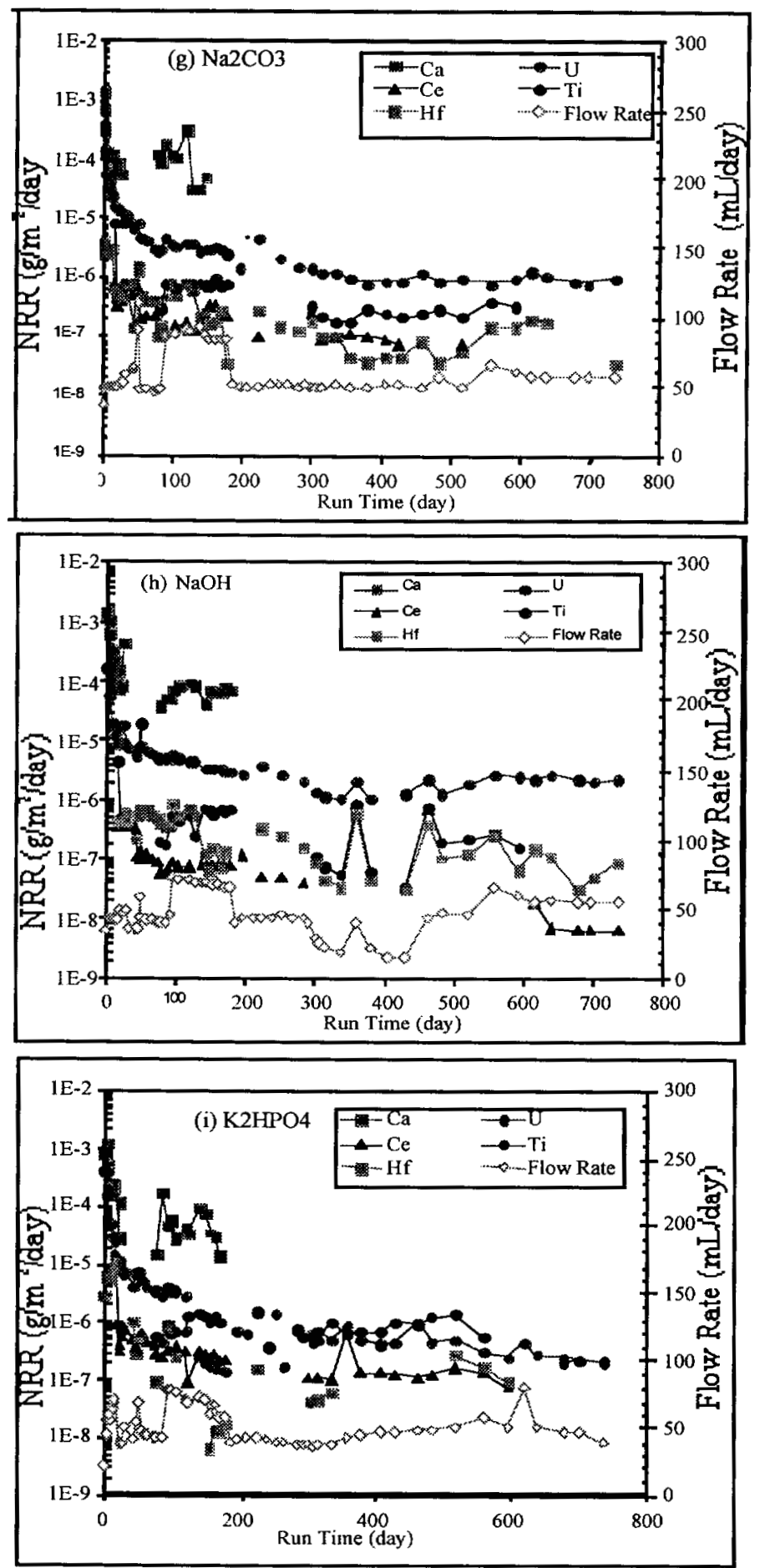

Figure 3 (cont). Normalized release rates of major elements in U-Ce multi-phase pyrochlore ceramic waste form (P104) and flow rates in three different buffers $(\mathrm{g}) \mathrm{Na}_{2} \mathrm{CO}_{3}$, (h) $\mathrm{NaOH}$, and (i) $\mathrm{K}_{2} \mathrm{HPO}_{4}$ ) at $\mathrm{pH} 12$. 

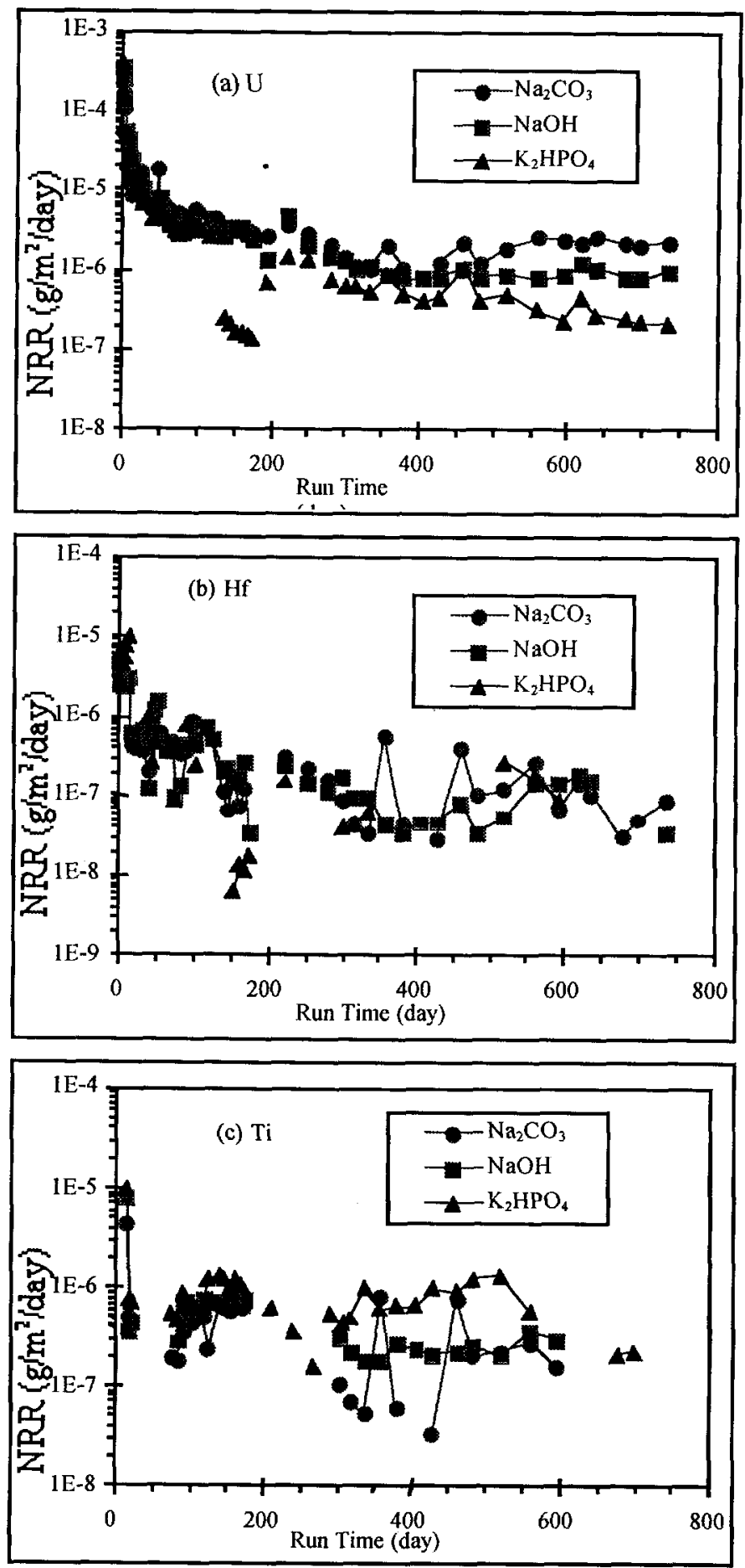

Figure 4. Effects of $\mathrm{pH}$ buffer chemistry on the dissolution rates of (a) U, (b) Hf and (c) Ti in U-Ce multi-phase pyrochlore-based ceramic waste form at $\mathrm{pH} 12$. 

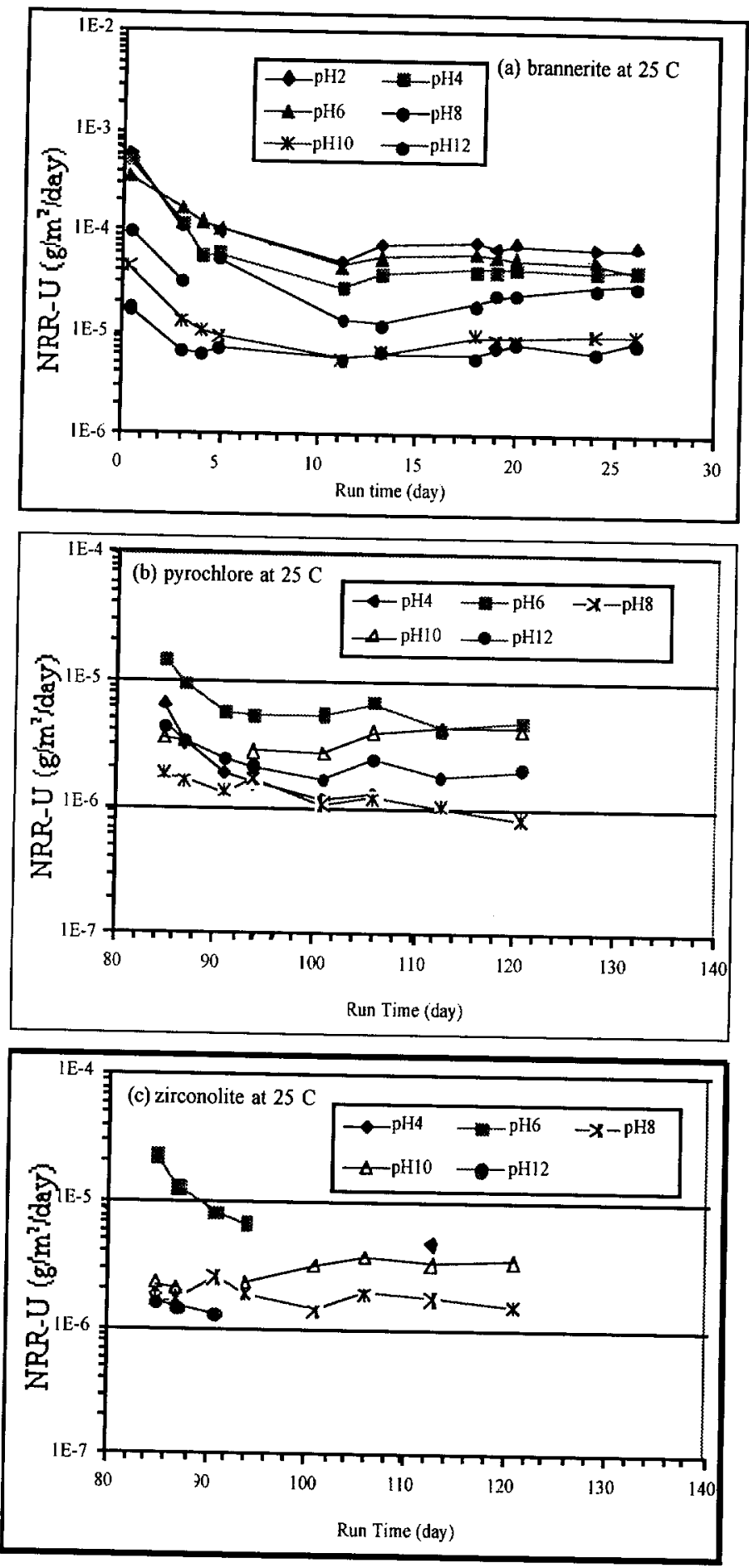

Figure 5. Normalized release rates of uranium from single-phase ceramics at $25^{\circ} \mathrm{C}$ for (a) brannerite, (b) pyrochlore, and (c) zirconolite. As-batched bulk compositions given in Table 1. 

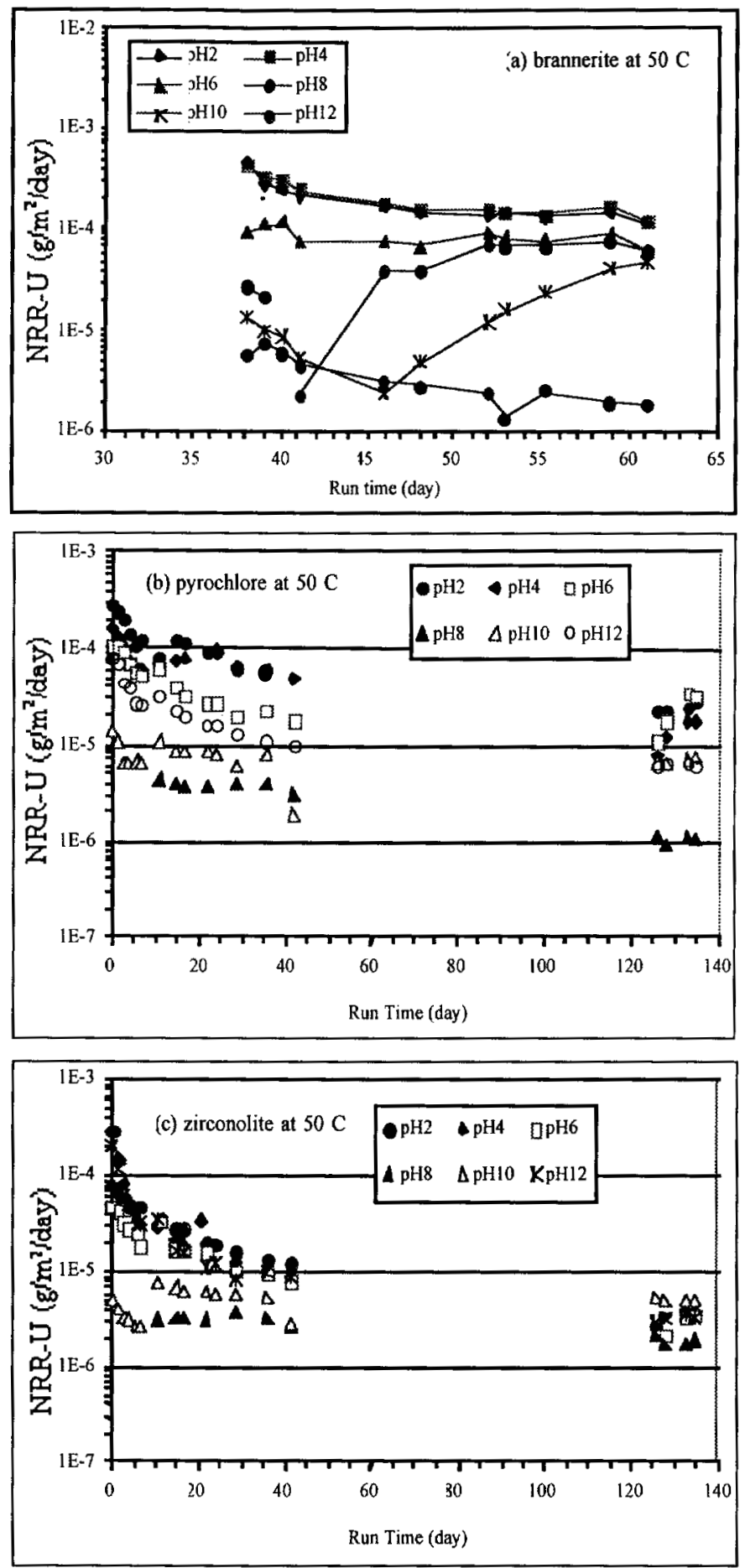

Figure 6. Normalized release rates of uranium from single-phase ceramics at $50^{\circ} \mathrm{C}$ for (a) brannerite, (b) pyrochlore, and (c) zirconolite. 

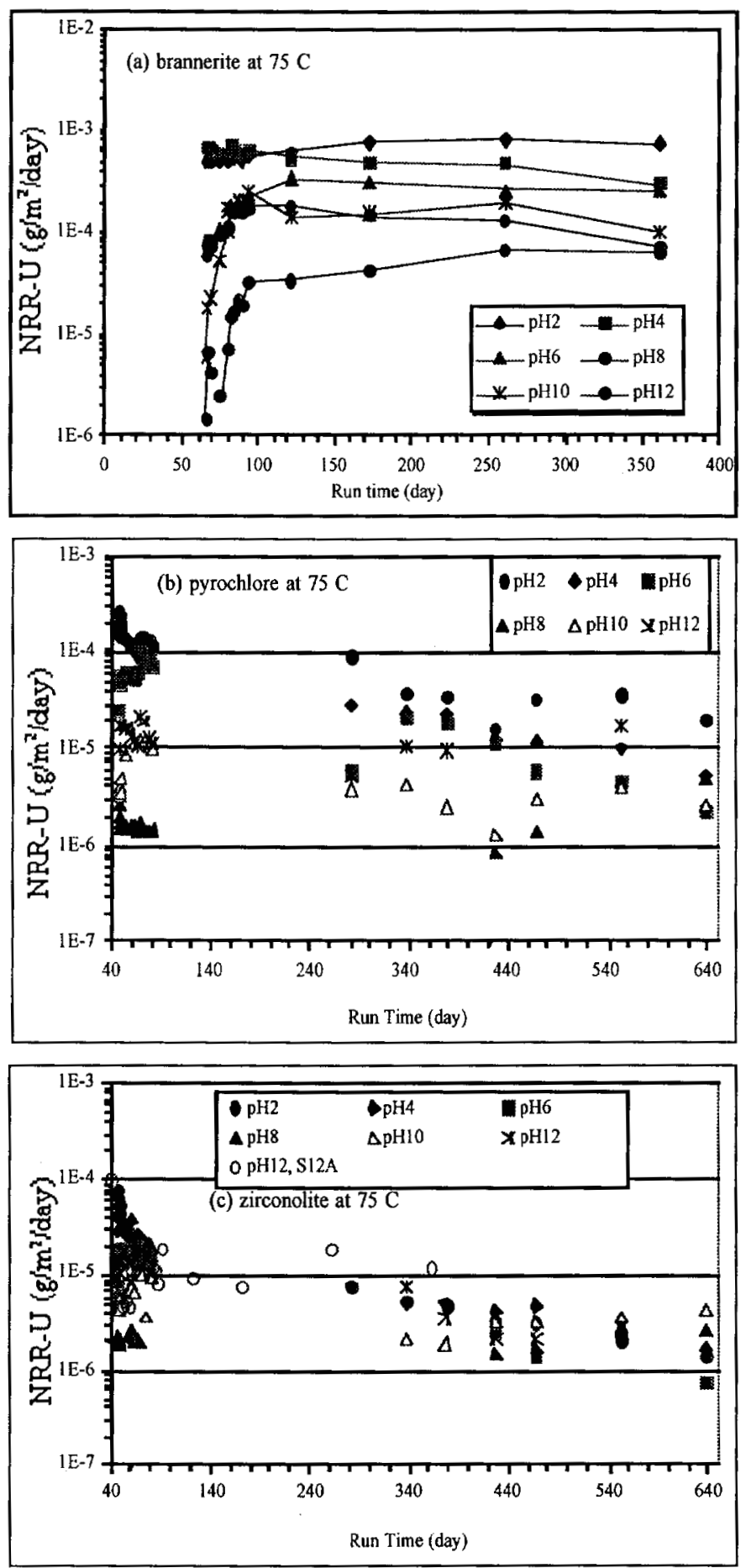

Figure 7. Normalized release rates of uranium from singlephase ceramics at $75^{\circ} \mathrm{C}$ for (a) brannerite, (b) pyrochlore, and (c) zirconolite. 


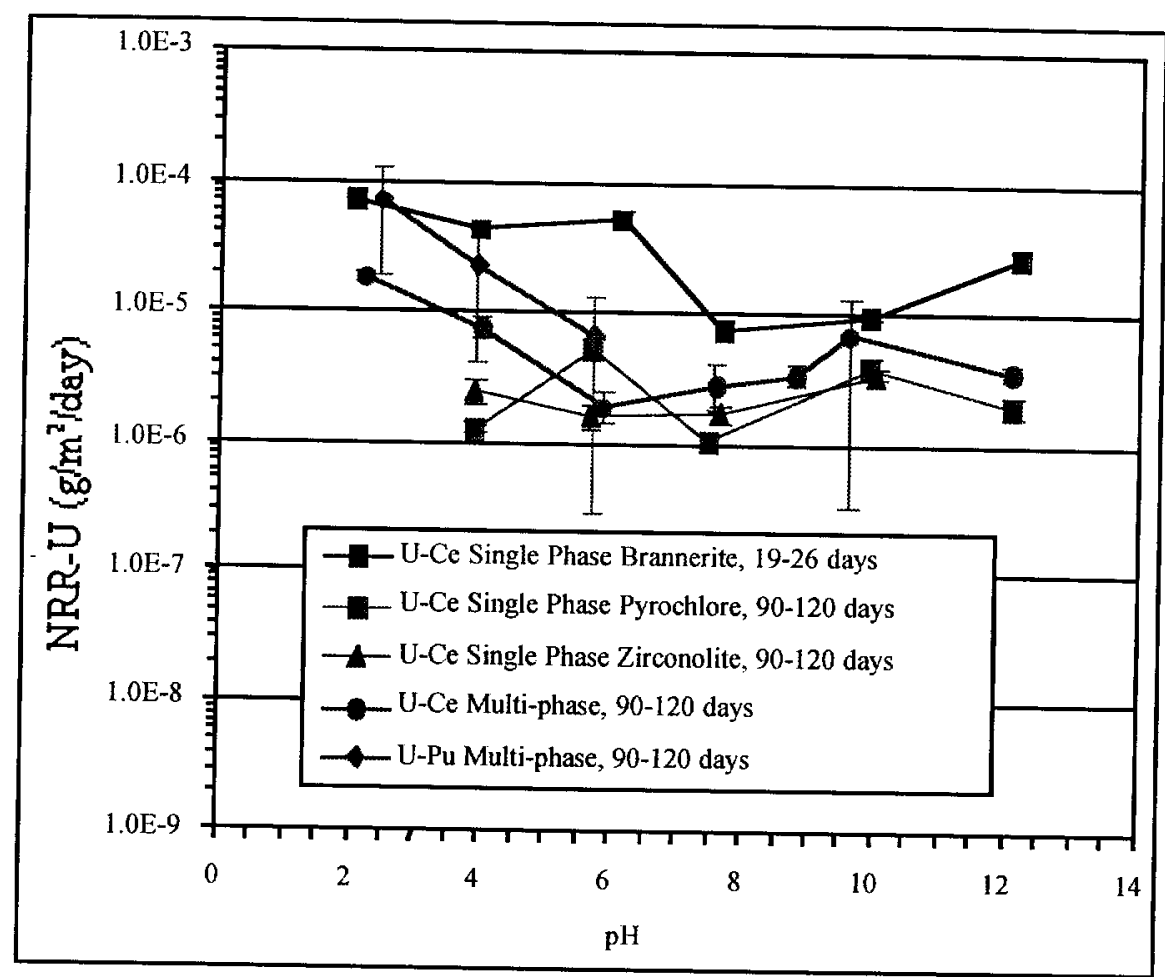

Figure 8. Comparison of dissolution rates of uranium from multi-phase and single phase tests as a function of $\mathrm{pH}$ at $25^{\circ} \mathrm{C}$. 


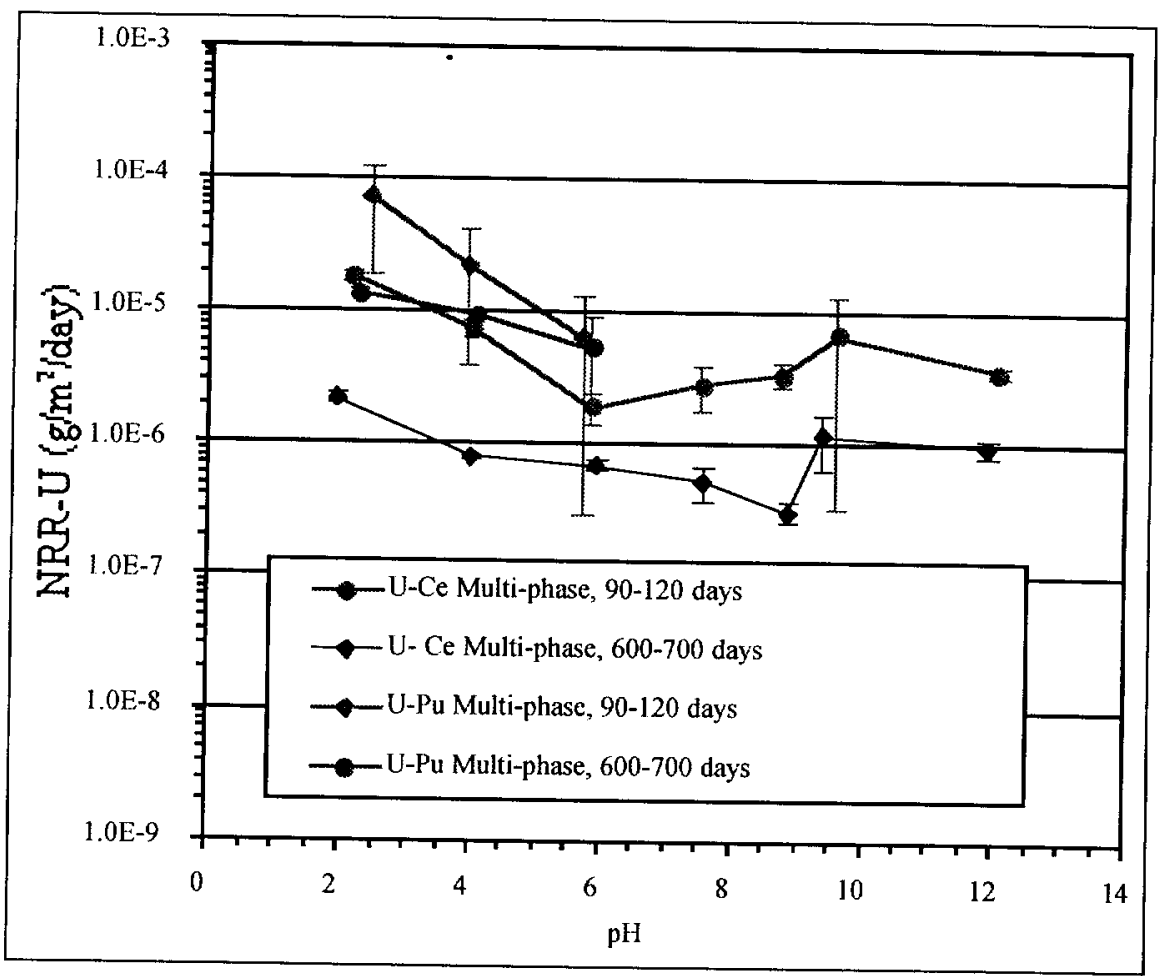

Figure 9. Comparison of dissolution rates of uranium from U-Ce vs. U-Pu ceramics as a function of $\mathrm{pH}$ at room temperature. 


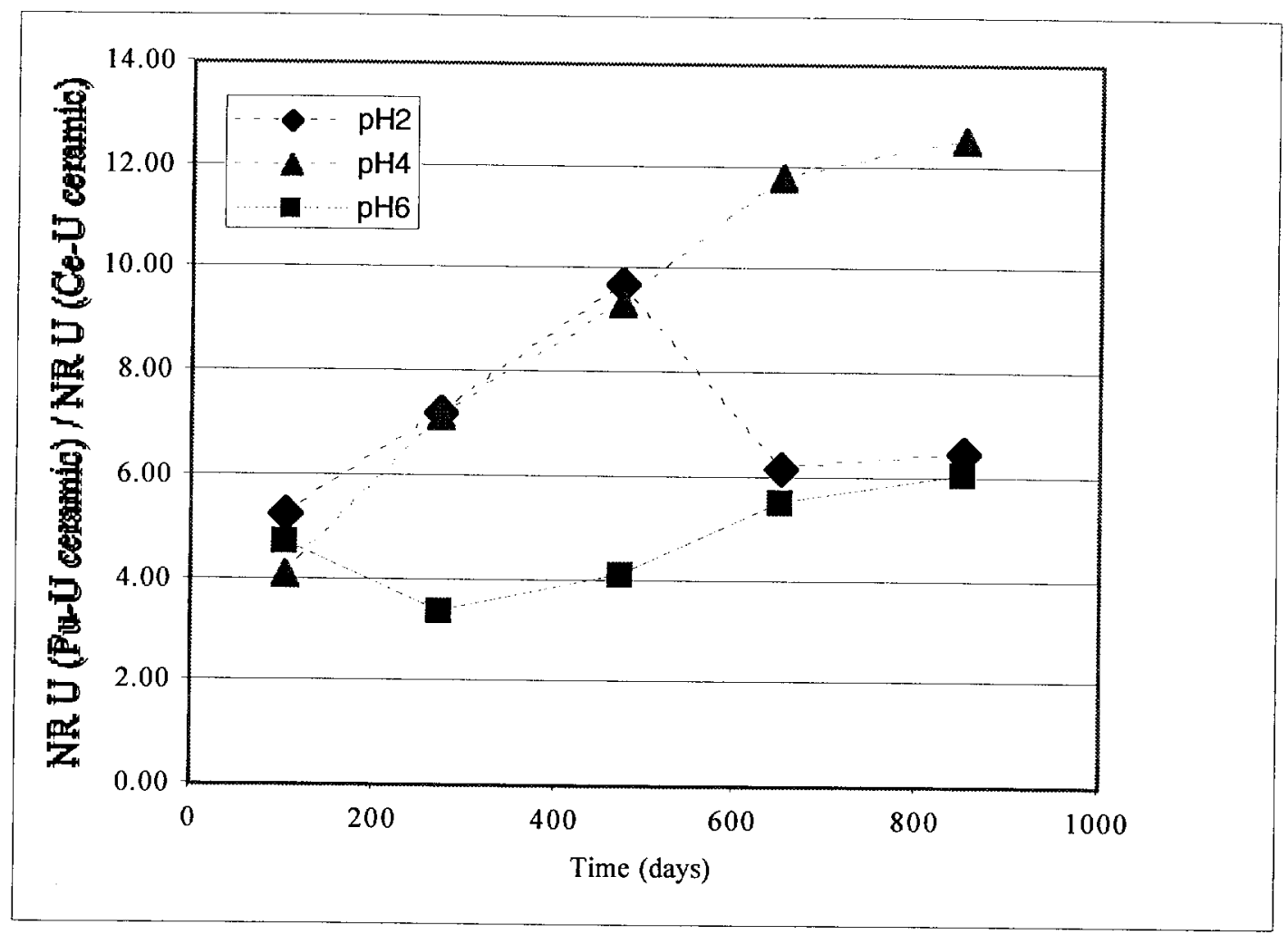

Figure 10. Comparison of uranium release rates from $\mathrm{Pu}-\mathrm{U}$ and $\mathrm{Ce}-\mathrm{U}$ ceramics. The ratio of $N R$ of $U$ from the Pu-U ceramic over the NR of $U$ from the Ce- $U$ ceramic is plotted vs. time. At greater times, the relative durability of the $\mathrm{Ce}-\mathrm{U}$ ceramic increases relative to the $\mathrm{Pu}-\mathrm{U}$ ceramic, perhaps indicating some deterioration in durability due to radiation damage by $\mathrm{Pu}$ in the $\mathrm{Pu}-\mathrm{U}$ ceramic. 


\section{Appendices}

The appendices contain all data obtained from the single-pass flow through tests of the ceramic waste forms.

Appendix A. Pu-U Multi-phase Pyrochlore-based Ceramic Waste Form Appendix B. Ce-U Multi-phase Pyrochlore-based Ceramic Waste Form Appendix C. Ce-U Single Phase Zirconolite Appendix D. Ce-U Single Phase Pyrochlore Appendix E. Ce-U Single Phase Brannerite

Notes:

1. Surface areas measured using nitrogen BET. Surface area of Pu-U ceramic material was estimated based on particle size and comparison with BET measurements of Ce-U material.

2. "Mass" refers to mass of ceramic powder used in test.

3. "Surf Area" is calculated surface area based on starting mass, BET measurement, and a correction term that takes into account surface area loss over duration of experiment as particles decrease in size. The calculation assumes smooth spherical particles and is based on uranium normalized release rates.

4. "NR" refers to normalized release rates for the element as defined on page 4 of text.

5. "\% loss" is calculated mass loss assuming stoichiometric dissolution and is based on uranium release. Uranium is generally the fastest released element. The \% loss is therefore a conservative upper limit on total mass released.

6. "Calc thickness" is the calculated thickness of material dissolved from the particle surface. As with '\% loss', it is calculated from the normalized release rate of uranium and assumes stoichiometric dissolution. As such it provides an estimate of the total amount of particle dissolution. "Calc thickness" can also be used as an estimate of the surface leached layer thickness assuming uranium is preferentially released from the surface layer and the titanate framework remains. The more relevant interpretation depends on the $\mathrm{pH}$ of the test. At low $\mathrm{pH}$ values where release is nearly congruent, 'Calc thickness' corresponds to the thickness of material that has been dissolved from the surface. At neutral $\mathrm{pH}$ values where release is incongruent (uranium is released more quickly than $\mathrm{Ti}, \mathrm{Hf}$ and other elements), it is a better estimate for leached layer thickness. 
plot of relative rates of $\mathrm{Ce}-\mathrm{U}$ ceramic vs. $\mathrm{Pu}-\mathrm{U}$ ceramic at $\mathrm{pH} 2,4$, and 6 (to see if rad damage is increasing the dissolution rate of the $\mathrm{pU}$ ceramic relative to the Ce ceramic)

\section{NR values of $U$ release}

$\begin{array}{cccccc} & & \mathrm{pH} 2 & \mathrm{pH} 4 & \mathrm{pH} 6 & \\ \text { Pu-U ceramic } & \text { days } & & & & \\ & 90-120 & 9.89 \mathrm{E}-05 & 3.20 \mathrm{E}-05 & 9.04 \mathrm{E}-06 & \\ & 250-300 & 7.47 \mathrm{E}-05 & 1.88 \mathrm{E}-05 & 6.77 \mathrm{E}-06 & \\ & 450-500 & 2.91 \mathrm{E}-05 & 1.10 \mathrm{E}-05 & 2.82 \mathrm{E}-06 & \\ & 600-700 & 1.35 \mathrm{E}-05 & 9.27 \mathrm{E}-06 & 5.22 \mathrm{E}-06 & \\ & 800-900 & 1.04 \mathrm{E}-05 & 8.87 \mathrm{E}-06 & 4.31 \mathrm{E}-06 & \\ & & & & & \\ \text { Ce-U ceramic } & 90-120 & 1.88 \mathrm{E}-05 & 7.80 \mathrm{E}-06 & 1.92 \mathrm{E}-06 & \\ & 250-300 & 1.04 \mathrm{E}-05 & 2.62 \mathrm{E}-06 & 2.02 \mathrm{E}-06 & \\ & 450-500 & 2.99 \mathrm{E}-06 & 1.18 \mathrm{E}-06 & 6.94 \mathrm{E}-07 & \\ & 600-700 & 2.19 \mathrm{E}-06 & 7.87 \mathrm{E}-07 & 9.47 \mathrm{E}-07 & \\ & 800-900 & 1.60 \mathrm{E}-06 & 7.08 \mathrm{E}-07 & 7.11 \mathrm{E}-07 & \\ & & & & & \\ \text { Ratio Pu/Ce } & \text { days } & 2 & 4 & 6 & \text { days } \\ & 90-120 & 5.26 & 4.11 & 4.71 & 105 \\ & 250-300 & 7.22 & 7.16 & 3.35 & 275 \\ & 450-500 & 9.75 & 9.36 & 4.07 & 475 \\ & 600-700 & 6.15 & 11.77 & 5.52 & 650 \\ & 800-900 & 6.51 & 12.52 & 6.06 & 850\end{array}$

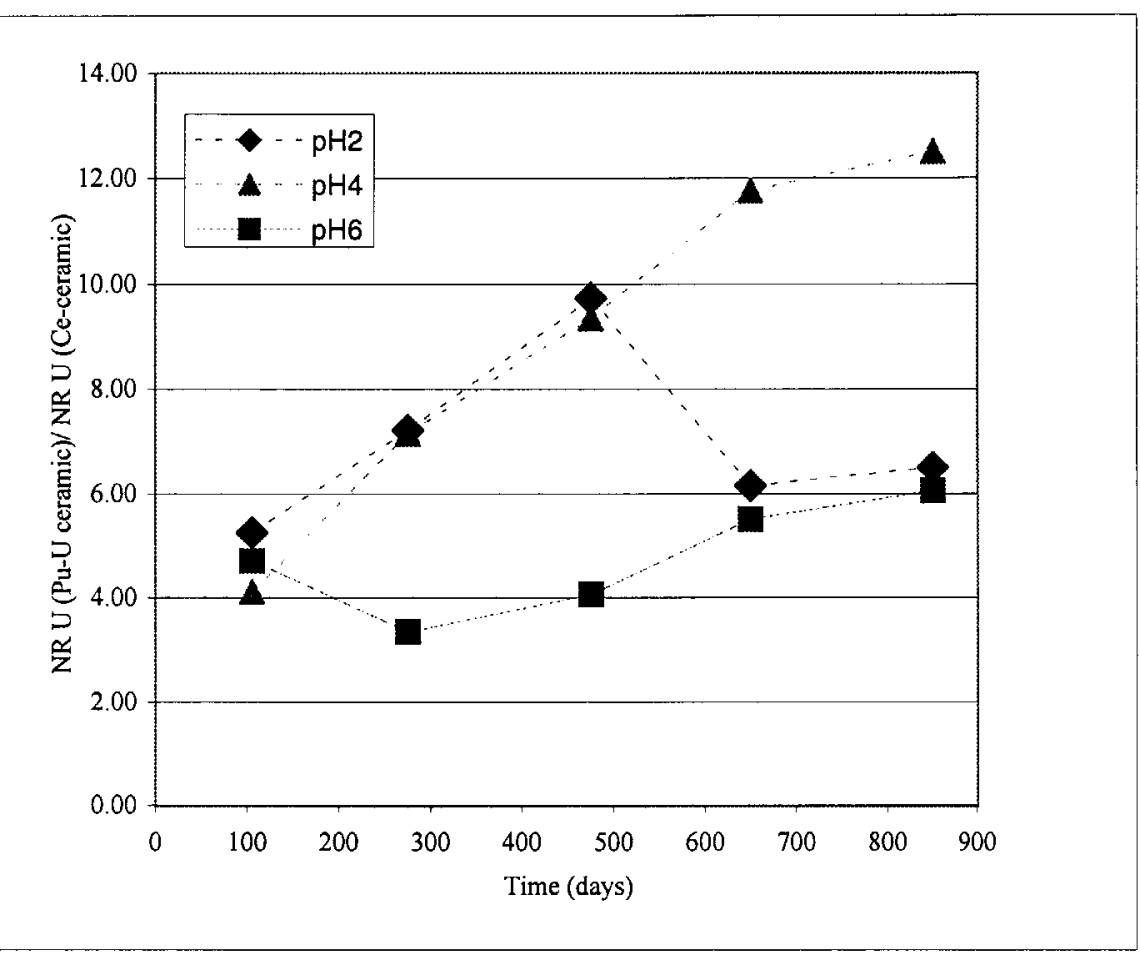

